\title{
Evaluation of estrogenic pathway genes in the vagina of rats treated with genistein or estrogen immediately or later after castration
}

\author{
Carbonel A.A.F ${ }^{1}$, Simões RS $^{2}$, Santos M.A ${ }^{1}$, Reis L.A ${ }^{3}$, Maganhin C.C ${ }^{1}$, Bertoncini C.R.A ${ }^{4}$, Baracat \\ E.C ${ }^{2}$, Simões M.J ${ }^{1}$, Soares Jr J.M ${ }^{2}$ \\ ${ }^{1}$ Department of Morphology and Genetics, Federal University of São Paulo, UNIFESP -Brazil \\ 2 Department of Obstetrics and Gynecology, University of São Paulo, USP-Brazil \\ ${ }^{3}$ Department of Nephrology, Federal University of São Paulo, UNIFESP - Brazil \\ ${ }^{4}$ Center for Development of Experimental Models for Medicine and Biology - CEDEME, Federal \\ University of São Paulo, UNIFESP - Brazil.
}

To evaluate the activity of genes ESR1, ESR2, VEGF and MKI67 in the vagina of rats treated with $17 \beta$-estradiol $(5 \mu \mathrm{g} / \mathrm{Kg})$ or genistein $(50 \mathrm{mg} / \mathrm{Kg})$ after castration. Methods: We used 60 adult rats castrated divided into six groups GI = received vehicle (propylene glycol); immediately after castration; $\mathrm{GII}=$ received genistein immediately after castration; GIII = received genistein 30 days after castration; $\mathrm{GIV}=$ received only the vehicle after 30 days of castration; GV = received $17 \beta$-estradiol immediately after castration; GVI = received $17 \beta$-estradiol after 30 days of castration. Drugs were administered by gavage $(0.5 \mathrm{ml})$ for 30 consecutive days, and after the last administration, the animals were anesthetized and the vaginas were removed. A part of this was dipped in liquid nitrogen for gene expression analysis by RT-PCR method, and the other part was fixed in 10\% formalin for histological processing. Sections were stained by hematoxylin and eosin or subjected to immunohistochemistry for evaluation of VEGF-A (vascular growth factor) and Ki-67 (cell proliferation). The analysis of gene expression by quantitative PCR were performed on a custom plate to the signaling pathway of estrogen. Results: The gene expression of ESR1, ESR2, VEGF and MKi-67 was higher in the groups treated with 17 $\beta$-estradiol and GIII showed the highest expression of ESR2 gene. The thickness of the vaginal epithelium, irrigation (VEGF-A) (fig.1) and cell proliferation (Ki-67) (fig.2) were higher for the GIV and GV, and the data were similar to those found in the analysis of gene expression. The gene expression of ESR1 receptor (alpha) and ESR2 (beta) was higher in GIV and GV, whereas the largest increase was observed in the of beta type (fig.3) Conclusion: Our data showed that genistein has positive effects on the vagina of rats, but this action is less than estrogen.

\section{References:}

Carbonel AA, Baracat MC, Simões RS, Simões MJ, Baracat EC, Soares JM Jr. Thesoybean concentrated extract proliferates the vagina of adult rats. Menopause.2011 Jan;18(1):93-101. 


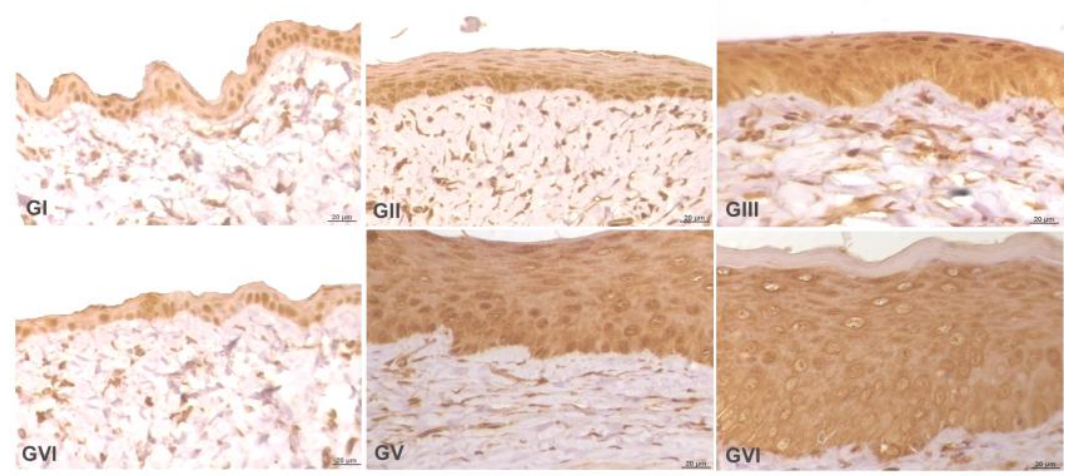

Figure 1 - Photomicrographs of uterine sections subjected to immunohistochemistry for the detection of VEGF-A, in rats of the different study groups. (400X).

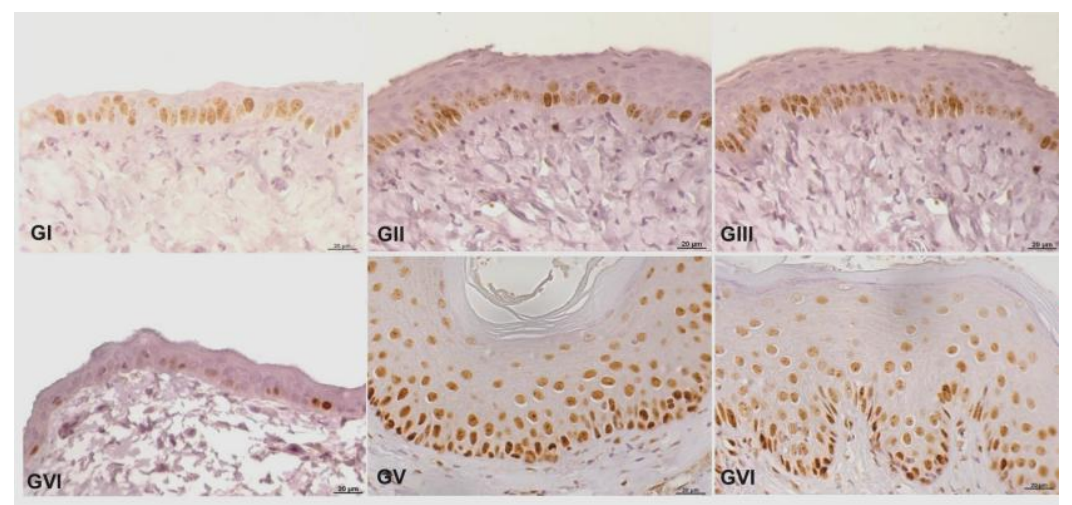

Figure 2 - Photomicrographs of uterine segments immunohistochemically reactive to Ki67 and originating from rats in the different study groups. Note surface epithelium (SE) with clusters of proliferating cells in the groups treated late (GIV and GVI) compared to groups treated immediately after ovariectomy (GIII and GV) (arrows). (400X)
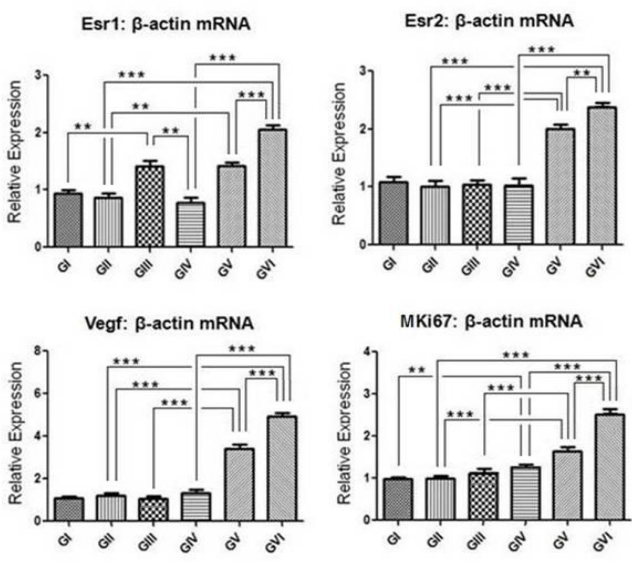

Figure 3 - The qRT-PCR analysis of the relative expression of genes highly expressed in the vagina of rats treated with $17 \beta$-estradiol or genistein immediately or later after oophorectomy. $\left({ }^{*} p<0.05\right.$; $* * \mathrm{p}<0.01 ; * * * \mathrm{p}<0.001)$. 